\title{
ANTIBACTERIAL NANOCOMPOUND BASED ON SILICONE RUBBER. PART I - OBTAINING AND CHARACTERISATION
}

\section{Mihaela NITUICĂ (VÎLSAN)*, Maria SÖNMEZ, Mihai GEORGESCU, Dana GURĂU, Olga NICULESCU}

INCDTP - Division Leather and Footwear Research Institute, 93 Ion Minulescu St., sector 3, Bucharest, mihaela.nituica@icpi. ro, mihaelavilsan@yahoo.com

ABSTRACT. The purpose of this paper is to develop an antibacterial polymer nanocompound based on silicone rubber reinforced with $\mathrm{TiO}_{2}$ nanoparticles and with added crosslinkers - dicumyl peroxide. The antibacterial nanocompound polymer was developed by vulcanization on a laboratory roll mill, so as to be further processed by means of molding using the electric press, with preset parameters for optimum processing. The antibacterial polymer nanocompound obtained was characterized in terms of physical-mechanical properties in normal condition and after accelerated aging at $70^{\circ} \mathrm{C}$ for 168 hours; it was also characterized in terms of immersion in specific environments for the food and pharmaceutical industries according to standards in force, and structurally by FT-IR. The new advanced material based on silicone elastomer (silicone rubber) helps to improve product quality, protects human health, sterilizes products against bacteria and microbes and last but not least protects the environment, but also increases the turnover of domestic and international companies. Following physical-mechanical and chemical characterization of polymer nanocompounds, two variants were selected $\left(P_{5}\right.$ and $\left.P_{6}\right)$ which have potential applications in food and pharmaceutical industries.

KEY WORDS: silicone rubber, polymer nanocompound, vulcanization, antibacterial nanocompound

\section{NANOCOMPOUND ANTIBACTERIAN PE BAZĂ DE CAUCIUC SILICONIC. PARTEA I - OBȚINERE ȘI CARACTERIZARE}

REZUMAT. Scopul acestei lucrări este obținerea unui nanocompound polimeric antibacterian pe bază de cauciuc siliconic, ranforsat cu nanoparticule de $\mathrm{TiO}_{2}$ și adaosuri de agenți de reticulare - peroxid de dicumil. Nanocompoundul polimeric antibacterian s-a realizat prin vulcanizare pe un valt de laborator, astfel încât să poată fi prelucrat prin metode de formare (în matriță) în presa electrică, la parametri de procesare optimi prestabiliți. Nanocompoundul polimeric antibacterian obținut a fost caracterizat din punct de vedere fizico-mecanic în stare normală și după îmbătrânire accelerată la temperatura de $70^{\circ} \mathrm{C}$, timp de $168 \mathrm{~h}$; din punct de vedere al imersiei în medii specifice domeniilor alimentar și farmaceutic, conform standardelor în vigoare; și structural prin spectroscopie FT-IR. Noul material avansat, pe bază de elastomer siliconic (cauciuc siliconic), contribuie la îmbunătățirea calității produselor, protecției sănătății omului, sterilizarea antibacteriană și antimicrobiană a produselor obținute și nu în ultimul rând la protecția mediului, dar și la creșterea cifrei de afaceri a agenților economici autohtoni și internaționali. În urma caracterizării fizico-mecanice și chimice a nanocompoundurilor polimerice obținute, s-au selectat două variante de nanocompounduri $\left(\mathrm{P}_{5}\right.$ și $\left.\mathrm{P}_{6}\right)$ ce au potențiale aplicații în industria alimentară și farmaceutică. CUVINTE CHEIE: cauciuc siliconic, nanocompound polimeric, vulcanizare, nanocompound antibacterian

\section{NANOCOMPOSITE ANTIBACTÉRIEN À BASE DE CAOUTCHOUC DE SILICONE. PARTIE I - OBTENTION ET CARACTÉRISATION}

RÉSUMÉ. Le but de cet article est d'obtenir un nanocomposite de polymère antibactérien à base de caoutchouc de silicone renforcé avec des nanoparticules de $\mathrm{TiO}_{2}$ et réticulé avec le peroxyde de dicumyle. Le nanocomposite de polymère antibactérien a été réalisé par vulcanisation sur un moulin de laboratoire, de manière à être traité ultérieurement par moulage à l'aide de la presse électrique, selon les paramètres prédéterminés pour le traitement optimal. Le nanocomposite de polymère antibactérien obtenu a été caractérisé du point de vue physique et mécanique dans un état normal et après le vieillissement accéléré à $70^{\circ} \mathrm{C}$ pendant 168 heures; il a été aussi caractérisé par l'immersion dans des environnements spécifiques pour l'industrie alimentaire et pharmaceutique selon les normes en vigueur, et structurellement par FT-IR. Le nouveau matériel avancé à base d'élastomère silicone (caoutchouc de silicone) contribue à améliorer la qualité des produits, protége la santé humaine, stérilise les produits contre les bactéries et les microbes et non moins protège l'environnement, mais aussi il augmente le chiffre d'affaires des entreprises nationales et internationales. Suite à la caractérisation physique, mécanique et chimique du nanocomposite de polymère obtenu, on a sélectionné deux variantes de nanocomposites $\left(P_{5}\right.$ et $\left.P_{6}\right)$ qui ont des applications potentielles dans l'industrie alimentaire et pharmaceutique.

MOTS-CLÉS: caoutchouc de silicone, nanocomposite de polymère, vulcanisation, nanocomposite antibactérien

\section{INTRODUCTION}

Worldwide there is a need to develop new advanced materials based on silicone elastomers (silicone rubber) with enhanced properties, reinforced with nanopowders with antimicrobial, antibacterial, and antifungal properties ( $\mathrm{ZnO}$ and $\left.\mathrm{TiO}_{2}\right)[1,2]$. Vulcanization process as the main stage has a major impact on the final properties of the product, including determination of the optimal amount of nanometric reinforcing filler and crosslinking agent used (peroxides) [3-6].
Reinforcing agents in the nanometric range provide antibacterial, antiseptic and antifungal properties, help initialize the vulcanization process, and also improve physical, mechanical and chemical properties, especially elasticity, tensile strength, resistance to aggressive chemical agents, etc.

Silicone elastomers are polymers with special characteristics due to their high resistance to temperatures from $\left(-100^{\circ} \mathrm{C}\right)$ to above $\left(+300^{\circ} \mathrm{C}\right)$ $[7,8]$. These are high temperatures specific to

\footnotetext{
${ }^{*}$ Correspondence to: Mihaela NITUUIC̆, INCDTP - Division Leather and Footwear Research Institute, 93 Ion Minulescu St., Sector 3, Bucharest, Romania, email: mihaelavilsan @yahoo.com
} 
sterilization, used to make products for the food, pharmaceutical and medical industries. Items made of silicone elastomers (silicone rubber) are preferred in medicine because they do not contain substances such as antioxidants and other restricted ingredients [9-12].

This paper presents the development of polymer nanocompounds based on silicone rubber, reinforced with $\mathrm{TiO}_{2}$ nanoparticles filled with chalk $\left(\mathrm{CaCO}_{3}\right)$, with stearin as plasticizer and crosslinked with dicumyl peroxide (PD), which were characterized in terms of physicomechanical and chemical properties by immersion in specific environments for the pharmaceutical and food industries (alcohol, distilled water, cooking oil - sunflower oil) according to standards in force and structurally analysed by FT-IR.

\section{EXPERIMENTAL}

\section{Materials}

The following materials were used in order to make the antibacterial polymer nanocompound:

1. silicone rubber (Elastosil R701/70$\mathrm{OH}$ : polydimethylsiloxane with vinyl groups, (dynamic) viscosity above $9.000 .000 \mathrm{mPa} \times \mathrm{s}$, in the form of paste, density $-1.32 \mathrm{~g} / \mathrm{cm}^{2}$, colour opaque);

2. stearin (in the form of white flakes, moisture $-0.5 \% \max$, ash $-0.025 \% \max$ );

3. active zinc oxide ( $\mathrm{ZnO}-93-95 \%$ precipitate, white powder, density $-5.5 \mathrm{~g} / \mathrm{cm}$, specific area 45-55 $\mathrm{m}^{2} / \mathrm{g}$ );

4. titanium dioxide nanoparticles $\left(\mathrm{TiO}_{2}-\right.$ white nanopowder, assay $\geq 99.5 \%$ trace metals basis);

5. chalk $\left(\mathrm{CaCO}_{3}\right.$ precipitate - white powder, molecular weight 100.09);

6. di(tert-butylperoxyisopropyl) benzene, powder $40 \%$ with calcium carbonate and silica (PD) - Perkadox 14-40B (1.65 g/ $\mathrm{cm}^{3}$ density, 3.8\% active oxygen content, $\mathrm{pH} 7$, assay: 39.0-41.0\%).

\section{Preparation of Composites}

The antibacterial polymer nanocompound based on silicone rubber, reinforced with nanometric particles $\left(\mathrm{TiO}_{2}\right)$, filled with $\mathrm{CaCO}_{3}$ (chalk) and crosslinked with dicumyl peroxide (Perkadox - PD) was developed by electric laboratory roll mill mixing (with temperature adjustment), of $1 \mathrm{~kg}$ capacity, with cooling (rolls are water-cooled). Mixing was performed without heating the rolls. The order of adding ingredients was strictly observed, according to Table 1. Silicone rubber was plasticized between the rolls for approximately 3 minutes, the plasticizer - stearin - was added and mixing continued for 1.5 minutes; zinc oxide was then added (microparticle) and embedded into the mixture until homogenisation; $\mathrm{TiO}_{2}$ nanoparticles were added, continuing to mix for 3 minutes until the nanometric component was embedded; the filler $\left(\mathrm{CaCO}_{3}\right)$ was then added and mixing continued for 2-2.5 minutes; the last ingredient - dicumyl peroxide - is embedded into the mixture for 2 minutes. After adding all the ingredients, the mixture is homogenized on the roll mill for 1 to maximum 3 minutes and taken off in the form of a 3-4 mm thick sheet. The resulting nanocompound is tested rheologically to determine the optimal vulcanization time, in order to set the optimal parameters for electric press processing, TP 600, by compression between its plates at a temperature of $170^{\circ} \mathrm{C}$ and preset times. Work stages and conditions are as follows:

- $\quad$ Pressing at $300 \mathrm{KN}$ pressure depending on rheological values (2 min. pressing);

- Cooling - $10 \mathrm{~min}$.

After 24-hour conditioning at room temperature, samples were cut out from the sheets and tested in terms of physicalmechanical properties: normal condition - at room temperature - and accelerated ageing at $70^{\circ} \mathrm{C}$ for 168 hours.

Table 1: Formulations of antibacterial polymer nanocompounds based on silicone rubber

\begin{tabular}{lccccc}
\hline \multicolumn{1}{c}{ Symbol } & $\mathrm{MU}$ & $\mathrm{CS}_{1}$ & $\mathrm{P}_{5}$ & $\mathrm{P}_{6}$ & $\mathrm{P}_{7}$ \\
\hline Silicone rubber & $\mathrm{g}$ & 150 & 150 & 150 & 150 \\
Stearin & $\mathrm{g}$ & 7.5 & 7.5 & 7.5 & 7.5 \\
Zinc oxide (microparticles) & $\mathrm{g}$ & 6 & 4.5 & 3 & 1.5 \\
Titanium dioxide (nanoparticles) & $\mathrm{g}$ & - & 1.5 & 3 & 4.5 \\
Chalk (CaCO ${ }_{3}$ ) & $\mathrm{g}$ & 15 & 15 & 15 & 15 \\
$\mathrm{PD}$ (dicumyl peroxide $-40 \%$ - on silica and $\mathrm{CaCO}_{3}$ substrate) & $\mathrm{g}$ & 11.25 & 11.25 & 11.25 & 11.25 \\
\hline
\end{tabular}


The technological process for developing antibacterial polymer nanocompounds based on silicone rubber, reinforced with $\mathrm{TiO}_{2}$ nanoparticles is illustrated in Figure 1.

The analysis of physical-mechanical

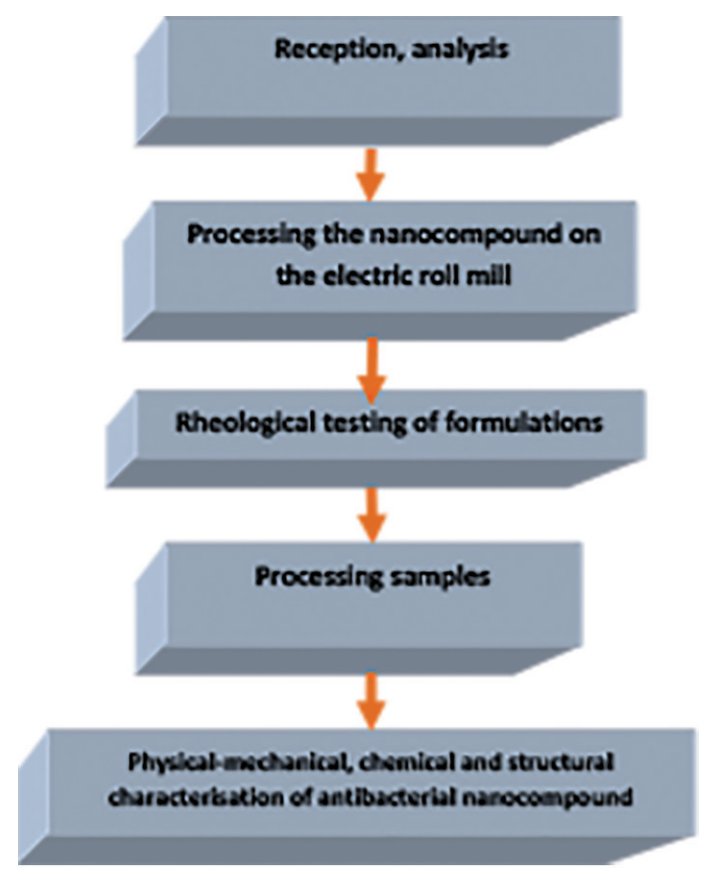

Figure 1. Stages of the technological process

for developing antibacterial polymer nanocompounds based on silicone rubber

\section{Characterization of Polymer Nanocompound}

The obtained polymer nanocompounds were tested in compliance with the physicalmechanical standards in effect: ${ }^{\circ} \mathrm{ShA}$ hardness SR ISO 7619:2011; elasticity \%, ISO 4662:2009; tensile strength, $\mathrm{N} / \mathrm{mm}^{2}$ - SR ISO 37-1997, normal condition and accelerated ageing, SR ISO 188-2010.

Table 2: Physical-mechanical testing of polymer nanocompounds based on silicone rubber reinforced with $\mathrm{TiO}_{2}$ nanoparticles

\begin{tabular}{|c|c|c|c|c|}
\hline Material & $\begin{array}{c}\mathrm{CS}_{1} \\
\text { (control) }\end{array}$ & $P_{5}$ & $P_{6}$ & $P_{7}$ \\
\hline \multicolumn{5}{|c|}{ Physical-mechanical characterization: normal condition } \\
\hline Hardness, ${ }^{\circ} \mathrm{Sh} \mathrm{A}$ & 65 & 64 & 54 & 53 \\
\hline Elasticity, \% & 12 & 10 & 08 & 07 \\
\hline Tensile strength, $\mathrm{N} / \mathrm{mm}^{2}$ & 3.4 & 3.8 & 3.3 & 3.0 \\
\hline \multicolumn{5}{|c|}{ Physical-mechanical characterization: accelerated ageing at $70^{\circ} \mathrm{C}$ and $168 \mathrm{~h}$} \\
\hline Hardness, ${ }^{\circ} \mathrm{Sh} \mathrm{A}$ & 71 & 70 & 68 & 63 \\
\hline Elasticity, \% & 12 & 09 & 08 & 07 \\
\hline Tensile strength, $\mathrm{N} / \mathrm{mm}^{2}$ & 3.4 & 3.0 & 3.1 & 2.5 \\
\hline
\end{tabular}

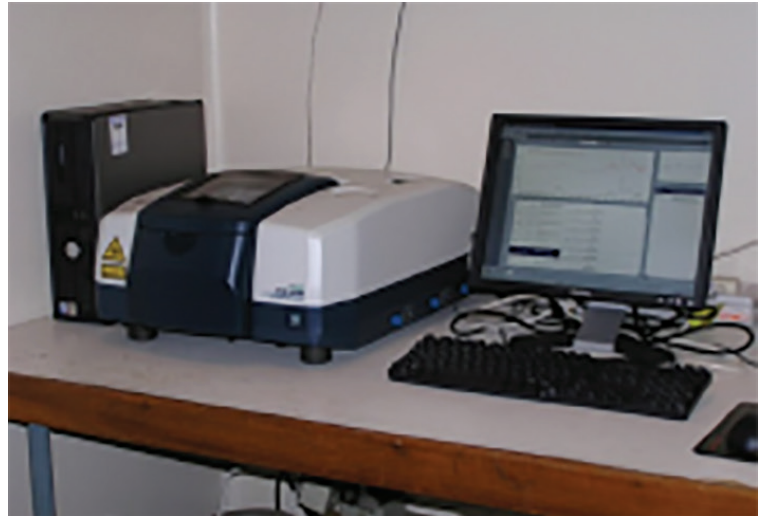

Figure 2. Able Jasco FT-IR 4200 spectrometer, coupled with ATR

Immersion in liquids was performed according to ISO 1817:2015 monitoring volume and mass variation. Samples used for immersion were $2 \pm 0.2 \mathrm{~mm}$ thick and their volume was $1-3$ $\mathrm{cm}^{3}$. Samples were immersed in tightly sealed recipients, for 24 hours.

Structural investigations were performed by FT-IR spectroscopy. Spectral determinations were performed using a double beam molecular absorption IR spectrometer, in the 4000-600 $\mathrm{cm}^{-1}$ range, using an FT-IR Able Jasco 4200 device coupled with ATR cu diamond crystal and sapphire head, Figure 2.

\section{RESULTS AND DISCUSSIONS}

\section{Physical-Mechanical Characterization of Antibacterial Polymer Nanocompounds}

Antibacterial polymer nanocompounds were tested and characterized according to standards in force. Table 2 presents values for physical-mechanical testing. 
characteristics (Table 2) shows the following:

- The hardness of antibacterial polymer nanocompounds based on silicone rubber reinforced with $\mathrm{TiO}_{2}$ nanoparticles shows changes compared to control sample $\mathrm{CS}_{1}$, and after accelerated ageing, hardness increases significantly compared to normal condition for all samples, due to plasticizer loss.

- Elasticity. Due to nanoparticle addition, a decrease in elasticity is noticed compared to the control sample. After accelerated ageing, elasticity decreases in all studied samples.

- Tensile strength. With the addition of reinforcing agent $\left(\mathrm{TiO}_{2}\right)$ and crosslinker (dicumyl peroxide), tensile strength shows values ranging from $3.0 \mathrm{~N} / \mathrm{mm}^{2}$ to $3.8 \mathrm{~N} / \mathrm{mm}^{2}$. Tensile strength therefore increases compared to control sample $\mathrm{CS}_{1}$ depending on the percentage of reinforcing agent added to the mixtures, and after accelerated ageing at $70^{\circ} \mathrm{C}$ for $168 \mathrm{~h}$, tensile strength shows much lower values compared to the control sample.

\section{Chemical Characterisation - Immersion of Antibacterial Polymer Nanocompounds}

The behaviour of mixtures was tested after immersion into various working environments ethyl alcohol (70\% ethyl alcohol concentration), distilled water, vegetable fat (sunflower cooking oil) for 24 hours at room temperature, in brown coloured tightly sealed recipients. Mass variation, $\Delta \mathrm{M}$, and volumetric variation, $\Delta \mathrm{V}$, were determined.

Values resulting from immersion are given in Table 3.

Values obtained for immersion of silicone rubber-based mixtures reinforced with $\mathrm{TiO}_{2}$ nanoparticles in various specific environments lead to the following conclusions:

- concentration of the nanometric reinforcing agent, $\mathrm{TiO}_{2}$, influences mass variation $(\Delta \mathrm{M})$ and volume variation $(\Delta \mathrm{V})$, both decreasing proportionally with the $\mathrm{TiO}_{2}$ percentage added to the antibacterial polymer compounds;

- in distilled water very good behaviour is noticed, below $1 \%$ for mass variation $(\Delta \mathrm{M})$ and $1.5 \%$ for volume variation $(\Delta V)$, indicating very low swelling in water;

- in ethyl alcohol and cooling oil (sunflower oil) variations are negative, below $\pm 4 \%$, indicating that in ethyl alcohol the extraction of a substance such as stearin, unreacted crosslinkers and chalk occurs, including in the vegetable oil immersion environment (sunflower oil).

\section{FT-IR Spectrometric Analysis}

The silicone rubber sample - ELASTOSIL $\mathrm{R} 701 / 70-\mathrm{OH}$, control sample - $\mathrm{CS}_{1}$, and antibacterial polymer nanocompounds $-\mathrm{P}_{5}$ and $\mathrm{P}_{6}$ were analysed by FT-IR spectroscopy.

As a result of determinations, the following were found:

1) The spectrum (Figure 3 ) recorded for the silicone rubber sample - ELASTOSIL R701/70-OH - shows IR frequencies $\left(\mathrm{cm}^{-1}\right)$ and vibration attributions given in Table 4.

2) The spectrum recorded for the

Table 3: Mass variation $(\Delta M)$ and volume variation $(\Delta V)$ of polymer nanocompounds based on silicone rubber reinforced with $\mathrm{TiO}_{2}$ nanoparticles in various environments

\begin{tabular}{|c|c|c|c|c|c|c|c|c|}
\hline \multirow[t]{2}{*}{ Material } & \multicolumn{2}{|c|}{$\begin{array}{c}\mathrm{CS}_{1} \\
\text { (control) }\end{array}$} & \multicolumn{2}{|c|}{$P_{5}$} & \multicolumn{2}{|c|}{$P_{6}$} & \multicolumn{2}{|c|}{$P_{7}$} \\
\hline & $\Delta \mathrm{M}$ & $\Delta \mathrm{V}$ & $\Delta \mathrm{M}$ & $\Delta \mathrm{V}$ & $\Delta \mathrm{M}$ & $\Delta \mathrm{V}$ & $\Delta \mathrm{M}$ & $\Delta \mathrm{V}$ \\
\hline Ethyl alcohol (70\%) & -0.76 & -1.11 & -1.52 & -2.07 & -1.21 & -1.71 & -0.77 & -1.66 \\
\hline Distilled water & 0.17 & 0.69 & 0.44 & 1.52 & 0.3 & 0.71 & 0.28 & \\
\hline Cooking oil (sunflower oil) & -1.23 & -1.65 & -2.15 & -3.31 & -2.22 & -2.94 & -2.32 & -2.43 \\
\hline \multirow{6}{*}{$\begin{array}{r}\text { Table 4: Frequencies and } \\
\text { for the silicone } r\end{array}$} & & & & Frequency & \multicolumn{3}{|c|}{ Vibration attributions } & \\
\hline & & & & 696 & \multicolumn{3}{|c|}{$\mathrm{v} \mathrm{Si}\left(\mathrm{CH}_{3}\right)_{3}$} & \\
\hline & & & & 787.271 & \multicolumn{3}{|c|}{ u Si $\left(\mathrm{CH}_{3}\right)$} & \\
\hline & r sam & & & 866.338 & \multicolumn{4}{|c|}{$\mathrm{Si}\left(\mathrm{CH}_{3}\right)_{2}(\mathrm{r})$} \\
\hline & & & & 1007.12 & \multicolumn{4}{|c|}{$\mathrm{Si}\left(-\mathrm{CH}_{3}=\mathrm{CH}_{2}\right)$} \\
\hline & & & & 1258.78 & \multicolumn{4}{|c|}{$\delta \mathrm{SiCH}$} \\
\hline
\end{tabular}




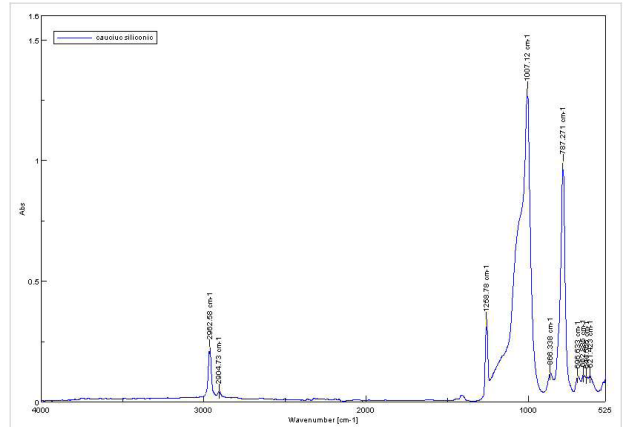

Figure 3. IR spectrum recorded for silicone rubber - ELASTOSIL R701/70-OH

Table 5: Frequencies and vibration attributions for the control sample

\begin{tabular}{cl}
\hline Frequency & Vibration attributions \\
\hline 697.141 & $\mathrm{u} \mathrm{Si}\left(\mathrm{CH}_{3}\right)_{3}$ \\
786.815 & $\cup \mathrm{Si}\left(\mathrm{CH}_{3}\right)$ \\
871.667 & $\mathrm{Si}\left(\mathrm{CH}_{3}\right)_{3}+\mathrm{Si}\left(\mathrm{CH}_{2}\right)_{2}$ \\
1006.66 & $\mathrm{Si}\left(-\mathrm{CH}_{3}=\mathrm{CH}_{2}\right)$ \\
1258.32 & $\delta \mathrm{SiCH}_{3}$ \\
1451.17 & $\cup \mathrm{CH}_{3}\left(\mathrm{CH}_{2}\right)_{16}-\mathrm{CO}$ - (stearic acid) \\
2849.31 & $\mathrm{Si}-\mathrm{O}-\mathrm{C}$ \\
3361.32 & $\cup(\mathrm{OH})$ linked \\
\end{tabular}

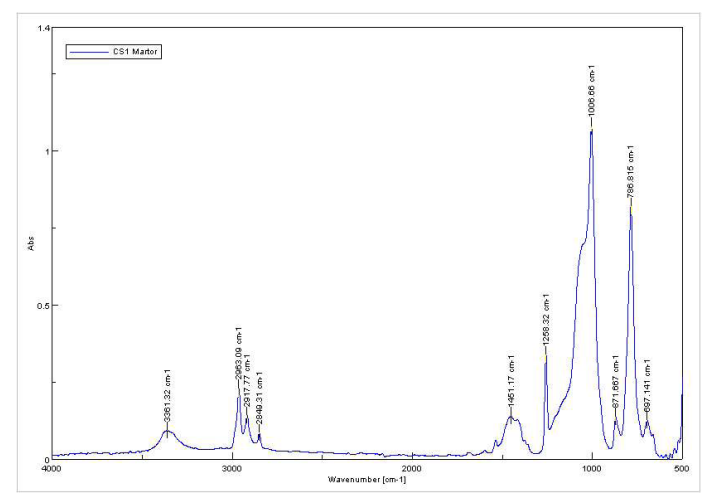

Figure 4. IR spectrum recorded for antibacterial polymer compound, control sample $-\mathrm{CS}_{1}$

Table 6: Frequencies and vibration attributions for antibacterial polymer nanocompound $\mathrm{P}_{5}$

\begin{tabular}{ll}
\hline Frequency & Vibration attributions \\
\hline 694.458 & $\cup \mathrm{Si}\left(\mathrm{CH}_{3}\right)_{3}$ \\
787.002 & $\cup \mathrm{Si}\left(\mathrm{CH}_{3}\right)$ \\
870.911 & $\mathrm{Si}\left(\mathrm{CH}_{3}\right)_{3}+\mathrm{Si}\left(\mathrm{CH}_{2}\right)_{2}$ \\
1005.09 & $\mathrm{Si}\left(-\mathrm{CH}_{3}=\mathrm{CH}_{2}\right)$ \\
1258.53 & $\mathrm{~S} \mathrm{SiCH}_{3}$ \\
1450.41 & $\cup \mathrm{CH}_{3}\left(\mathrm{CH}_{2}\right)_{16}-\mathrm{CO}$ - (stearic acid) \\
2850.48 & $\mathrm{Si}-\mathrm{O}-\mathrm{C}$
\end{tabular}

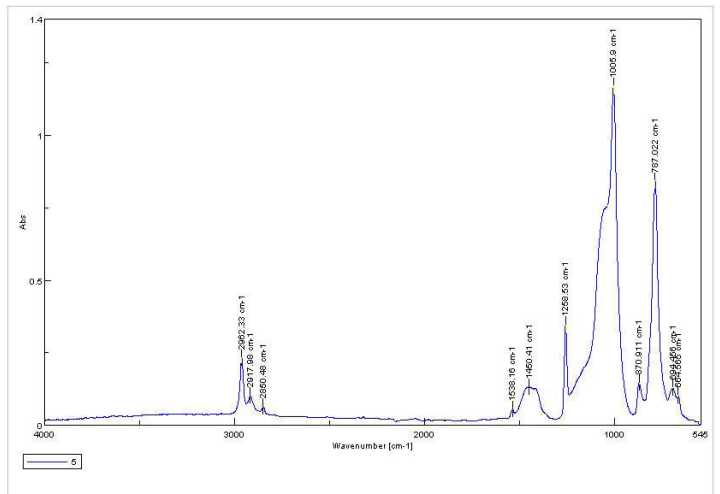

Figure 5. IR spectrum recorded for antibacterial polymer nanocompound, sample $\mathrm{P}_{5}$

Table 7: Frequencies and vibration attributions for antibacterial polymer nanocompound $\mathrm{P}_{6}$

\begin{tabular}{cl}
\hline Frequency & Vibration attributions \\
\hline 694.459 & $\cup \mathrm{Si}\left(\mathrm{CH}_{3}\right)_{3}$ \\
787.002 & $\cup \mathrm{Si}\left(\mathrm{CH}_{3}\right)$ \\
870.911 & $\mathrm{Si}\left(\mathrm{CH}_{3}\right)_{3}+\mathrm{Si}\left(\mathrm{CH}_{2}\right)_{2}$ \\
1005.9 & $\mathrm{Si}\left(-\mathrm{CH}_{3}=\mathrm{CH}_{2}\right)$ \\
1258.53 & $\delta \mathrm{SiCH}_{3}$ \\
1459.09 & $\cup \mathrm{CH}_{3}\left(\mathrm{CH}_{2}\right)_{16}-\mathrm{CO}-$ (stearic acid) \\
2849.52 & $\mathrm{Si}-\mathrm{O}-\mathrm{C}$ \\
\hline
\end{tabular}

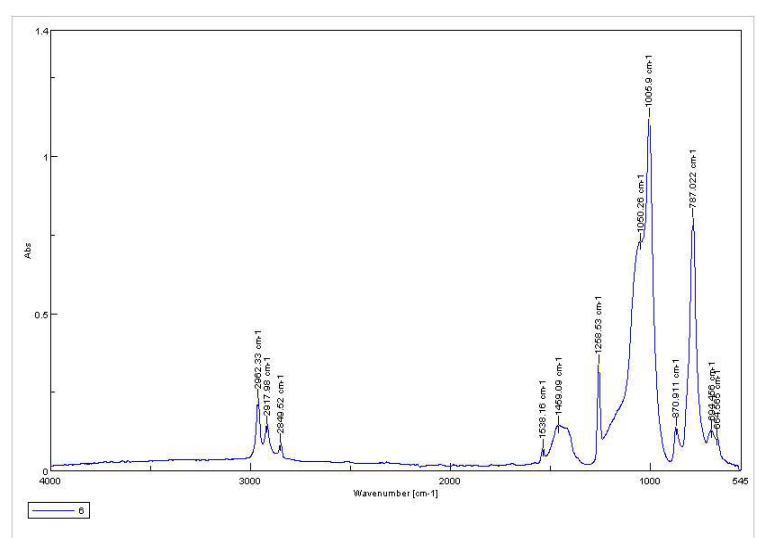

Figure 6. IR spectrum recorded for antibacterial polymer nanocompound, sample $P_{6}$

antibacterial polymer compound $\mathrm{CS}_{1}-$ control sample - is given in Table 5 .

3) The spectrum recorded for the antibacterial polymer nanocompound $P_{5}$ is given in Table 6.

4) The spectrum recorded for the antibacterial polymer nanocompound $\mathrm{P}_{6}$ is given in Table 7 .

IR spectra recorded for each nanocompound show that the disperse phase - silicone rubber (silicone elastomer) is in 
the highest amount, as it is the materials into which all other ingredients are embedded (the predominant material). The reinforcing agent in the form of nanoparticles $-\mathrm{TiO}_{2}$ - does not stand out due to its low amount and to its uniform embedding in the disperse phase.

\section{Conclusions}

This paper presents the technology for developing antibacterial polymer nanocompounds based on silicone rubber (silicone elastomer), plasticizer - stearin, filled with chalk, reinforced with $\mathrm{TiO}_{2}$ nanoparticles (with antifungal, antibacterial and antimicrobial properties) and crosslinked with dicumyl peroxide (PD).

After immersing samples in specific work environments, formulations do not undergo surface modifications in terms of colour change and cracking, which indicates that the technologies and processing parameters are optimal.

FT-IR spectra confirm the presence of silicone rubber by the intensity of the characteristic peaks of the predominant material (the material in which the other ingredients are embedded).

Given the resistance of nanometric reinforcing agent $-\mathrm{TiO}_{2}$ (with antimicrobial, antibacterial and antifungal role) to high temperatures, over $+300^{\circ} \mathrm{C}$, specific to sterilization, the polymer compounds based on silicone rubber may be used in the food and pharmaceutical industries.

Based on the values of physical-mechanical and chemical characteristics of antibacterial polymer nanocompounds based on silicone rubber, reinforced with $\mathrm{TiO}_{2}$ nanoparticles, variants $P_{5}$ and $P_{6}$ were selected for potential applications in the food and pharmaceutical industries.

\section{Acknowledgements}

This research was financed by ANCSI through NUCLEU Program 2016-2017, project code PN 163401 10: "Antibacterial compound based on silicone rubber and $\mathrm{ZnO}$ and $\mathrm{TiO}_{2}$ nanoparticles processed by vulcanization", contract no. $26 \mathrm{~N} / 2016$.

\section{REFERENCES}

1. Hanke, B., Bort, F., Anti-microbial silicone rubber composition and method for making same, US Patent 6,822,034 B2, 23 November 2004.
2. Shi, F., Clayman, R., Louie, M.K., Lin, Y.H., Lin, Y.C., Silicone composition and devices incorporating same, US Patent 8,257,827 B1, 4 September 2012.

3. Dobrinescu, A., New types of elastomers for special purposes, Ministry of Light Industry, Centre for Documentation and Technical Publications, Bucharest, 1971.

4. Volintiru, T., Ivan, Gh., Technological bases of processing elastomers, Technical Press, Bucharest, 1974.

5. Mirici, L.E., Thermoplastic Elastomers, Art. Press \& Augusta, Timisoara, 2005.

6. Petreus, O., Polymer Materials, Cermi, lasi, 1999.

7. Stelescu, M.D., Characteristics of silicone rubber blends, Leather and Footwear Journal, 2010, 10, 3, 51-58.

8. Fallahi, D., Mirzadeh, H., Khorasani, M.T., Physical, mechanical, and biocompatibility evaluation of three different types of silicone rubber, J Appl Polym Sci, 2003, 8, 2522-2529.

9. Mashak, A., In vitro drug release from silicone rubber-polyacrylamide composite, Silicon Chemistry, 2008, 3, 6, 295-301.

10. Malcolm, K., Woolfson, D., Russell, J., Tallon, P., Mc Auley, L., Craig, D., Influence of silicone elastomer solubility and diffusivity on the in vitro release of drug from intravaginal rings, J Control Release, 2003, 90, 2, 217-225.

11. Zhou, H., Wang, H., Niu, H., Gestos, A., Wang, X., Lin, T., Fluoroalkyl silane modified silicone rubber/nanoparticle composite: a super durable, robust superhydrophobic fabric coating, Adv Mater, 2012, 24, 24092412.

12. Hron, P., Slechtova, J., Smetana, K., Dvorankova, B., Lopour, P., Silicone rubber-hydrogel composites as polymeric biomaterials. IX. Composites containing powdery polyacrylamide hydrogel, Biomaterials, 1997, 18, 15, 1069-1073.

(C) 2017 by the author(s). Published by INCDTPICPI, Bucharest, RO. This is an open access article distributed under the terms and conditions of the Creative Commons Attribution license (http:// creativecommons.org/licenses/by/4.0/). 